\title{
PENGARUH KECERDASAN EMOSIONAL, ORGANIZATIONAL CITIZENSHIP BEHAVIOR, DAN KEPUASAN KERJA TERHADAP KINERJA KARYAWAN
}

\author{
Guruh Grahandika \\ Universitas Negeri Surabaya \\ guruhgrahandika@mhs.unesa.ac.id \\ Dewie Tri Wijayati \\ Universitas Negeri Surabaya \\ dewiewijayati@unesa.ac.id
}

Abstract

\begin{abstract}
This study aims to determine and analyze the effect of emotional intelligence, organizational citizenship behavior and job satisfaction on employee performance at PT. Perkebunan Nusantara X Pabrik Gula Lestari Nganjuk. This research is a type with a quantitative approach with a population of 185 permanent employees, and the sampling technique uses slovin sampling with a sample of 128permanentemployees. The analytical tool used is multiple linear regression analysis by IBM SPSS 25 software. The measurement scale used is the Likert Scale. The results of the study explained that emotional intelligence significantly and positively affects employee performance. Besides that, organizational citizenship behavior has a significant and positive impact on employee performance, and job satisfaction has a significant and positive effect on employee performance. The company should maintain its performance by building a communication and work culture that has been carried out based on the values of emotional intelligence, $O C B$ level, and employee satisfaction. In addition, it can also provide work motivation to employees in the company by providing rewards through various programs that can improve work performance and increase employee performance.
\end{abstract}

Keywords: emotional intelligence; employee performance; job statisfaction; organizational citizenship behavior.

\section{PENDAHULUAN}

Era globalisasi berdampak terhadap persaingan di dunia usaha. Globalisasi juga memberi kesempatan dan permasalahan baik dalam konteks kehidupan organisasi. Hal ini sangat bergantung dari prediksi serta kesiapan seluruh pihak yang terdapat dalam organisasi, baik para pemangku perusahaan ataupun karyawan. Di mana hal tersebut dapat membuka peluang untuk saling bekerja sama serta memenuhi kebutuhan organisasi ke depannya (Ardiana, 2008).

Sumber Daya Manusia (SDM) merupakan daya dorong utama bagi elemen-elemen suatu organisasi atau perusahaan dan memegang peranan penting di dalamnya. Untuk mencapai tujuan yang diharapkan, maka suatu organisai atau perusahaan harus mengembangkan sumber daya manusia sehingga dapat tetap bertahan dan bersaing. Maka dari itu untuk mewujudkannya, SDM yang terampil dan handal di lingkup pekerjaannya sangat diperlukan untuk mendorong kegiatan suatu perusahaan (Mathis \& Jackson, 2006).

Goleman (2004) menyatakan bahwa kemampuan seorang individu untuk merasakan perasaan sendiri dan juga perasaan orang lain, kemampuan seorang individu untuk mendorong diri sendiri dan menangani emosinya sendiri, serta kemampuan seorang individu dalam berhubungan baik dengan orang lain disebut sebagai kecerdasan emosional. Yusnaena \& Perdana (2015) adanya pengaruh secara positif dan signifikan kecerdasan emosional dan kinerja karyawan. Pratama \& Suhaeni (2017) menyatakan kecerdasan emosional dan kinerja karyawan terdapat pengaruh positif dan signifikan. Namun berbeda dengan hasil penelitian Yani \& Istiqomah (2016) secara negatif dan signifikan kecerdasan emosional memberikan pengaruh pada kinerja karyawan.

Bukan hanya dapat dipengaruhi oleh kecerdasan emosional, kinerja karyawan dapat pula dipengaruhi Organizational Citizenship Behavior (OCB) (Lesstari \& Ghaby, 2018; dan Suzana, 2017). Menurut Vipraprastha et al. (2018) OCB merupakan sikap inisiatif seorang individu yang bukan merupakan job description melainkan melakukannya secara sukarela tanpa menuntut imbalan untuk membantu 
mewujudkan tujuan perusahaan secara efektif dan efisien. Lesstari \& Ghaby (2018) menunjukkan hasil antara variabel OCB dan kinerja karyawan terdapat pengaruh secara positif dan signifikan. Penelitian Suzana (2017) pada karyawan TASPEN Cirebon membuktikan bahwa OCB memberikan pengaruh secara positif dan signifikan terhadap kinerja karyawan.

Kepuasan kerja ialah perilaku seorang karyawan pada tugas kewajibannya, yang berkaitan pula dengan faktor fisiologis dan psikologis maupun yang berhubungan dengan siatuasi kerja, kerja sama antar sesama rekan kerja serta rewart yang diterima oleh karyawan yang telah menyelesaikan suatu pekerjaan (Sutrisno, 2014). Fadhil \& Mayowan (2018) mengemukakan bahwa kepuasan kerja dan kinerja karyawan berpengaruh positif dan signifikan. Namun hasil ini berlawanan dengan Adiyasa \& Windayanti (2019) kepuasan kerja tidak berpengaruh secara signifikan terhadap kinerja karyawan.

Perusahaan yang dijadikan objek penelitian adalah Pabrik Gula Lestari Nganjuk. Berlokasi di Desa Ngrombot, Kecamatan Patianrowo, Kabupaten Nganjuk. Berdasarkan hasil observasi dan wawancara ke beberapa karyawan tetap bagian SDM, diketahui terdapat beberapa masalah dalam hal kinerja karyawan, di antaranya dari segi kecerdasan emosional yang dimiliki oleh karyawan, tingkat OCB yang ditunjukkan oleh karyawan, serta tingkat kepuasan yang dirasakan oleh setiap karyawan. Kecerdasan emosional yang dimiliki para karyawan perusahaan Pabrik Gula Lestari Nganjuk sudah cukup baik. Kemampuan karyawan dalam memotivasi diri sendiri terlihat pada beberapa karyawan yang dapat menyelesaikan masalah pekerjannya dengan segera mungkin. Karyawan mampu untuk mengambil inisiatif dan tindakan secara efektif dalam bekerja, selain itu karyawan juga mampu dan peka terhadap emosi yang dimiliki orang lain. Karyawan dapat menerima kritik serta saran yang membangun dari sesama rekan kerja atas tugas yang dikerjakannya. Hal-hal tersebut berkaitan dengan pengelolaan kecerdasan emosional di mana akan berdampak terhadap kinerja karyawan serta pencapaian dari suatu perusahaan sehingga ke depannya dapat memberikan dampak terhadap kestabilan hasil produksi. Selain hal tersebut, perilaku OCB juga terlihat cukup baik ditunjukkan oleh karyawan saat bekerja di Pabrik Gula Lestari, di mana terlihat bahwa saat di luar jam kerja karyawan membantu sesama rekan kerjanya di luar tugas utamanya. Tetapi, berdasarkan hasil pengamatan masih ada beberapa orang karyawan yang belum melakukan perilaku OCB, yang artinya bahwa karyawan tersebut masih acuh tak acuh terhadap lingkungan sekitarnya. Dalam segi kepuasan dalam bekerja, bebarapa karyawan merasa cukup puas terhadap apa yang dirasakan selama bekerja di lingkungan Pabrik Gula Lestari Nganjuk. Kepuasan tersebut di antaranya dalam hal sistem pemberian gaji. Selain itu juga ditemukan hal-hal yang meningkatkan kepuasan kerja karyawan, di antaranya adalah dukungan baik dari atasan maupun sesama rekan kerja sehingga dapat berpengaruh pada kinerja karyawan.

Berdasarkan permasalahan atau fenomena yang terdapat di Pabrik Gula Lestari Nganjuk serta ditemukan research gap dari penelitian sebelumnya, maka tujuan penelitian ini untuk mengetahui bagaimana pengaruh kecerdasan emosional, organizational citizenship behavior (OCB) dan kepuasan kerja terhadap kinerja karyawan Pabrik Gula Lestari Nganjuk.

\section{KAJIAN PUSTAKA DAN PENGEMBANGAN HIPOTESIS}

\section{Kecerdasan Emosional}

Goleman (2004) mendefinisikan di mana kecerdasan yang dimiliki oleh seorang individu yang merujuk terhadap kemampuan individu untuk mengenali perasaan dirinya sendiri dan juga orang lain, mampu dengan baik untuk mengendalikan emosinya sendiri dan menjalin hubungan yang baik dengan sesama. $80 \%$ keberhasilan seseorang dapat ditentukan oleh emotional quotient (EQ), dan $20 \%$ sisanya adalah intelligence quotient (IQ). Di mana kesuksesan seorang individu di masa depan tidak semata-mata di tentutan oleh IQ seseorang, melainkan juga ditentukan dengan adanya EQ. Kemampuan seorang individu yang dapat memotivasi diri sendiri diartikan juga sebagai kecerdasan emosional. Khan et al. (2019) mengartikan emotional intelligence sebagai kemampuan dalam memahami hal-hal terkait dengan emosi. Sedangkan menurut Mulyasari (2018) kecerdasan merupakan suatu kekuatan atau kemampuan diri untuk menguasai kemampuan tertentu. 
Pengukuran yang digunakan dalam penelitian ini ialah indikator Goleman (2004) terdiri dari bagaimana seorang individu dapat mengetahui keadaan dalam diri (self awareness), kemampuan seorang individu untuk mengelola keadaan dalam diri (self regulation), suatu pencapaian dan tujuan yang membutuhkan dorongan dalam diri (selfmotivation), sadar akan kepentingan serta perasaan maupun kepribadian orang lain (empaty), kemampuan dalam menangani emosi orang lain (social skill).

\section{Organizational Citizenship Behavior (OCB)}

Vipraprastha et al. (2018) menyatakan bahwa perilaku inisiatif individu yang melakukan pekerjan bukan merupakan job descriptionnya, melainkan melakukannya secara sukarela tanpa menuntut imbalan untuk membantu mewujudkan tujuan perusahaan secara efektif dan efisien merupakan organizational citizenship behavior (OCB). Sharma \& Mahajan (2017) menyatakan bahwa OCB adalah perilaku seorang karyawan di luar ketentuan job descriptionnya. Hal tersebut ialah sukarela dari seorang karyawan untuk melaksanakan tugas tanapa menerima imbalan apapun.

Pengukuran yang digunakan dalam penelitian ini ialah indikator Gibson et al. (1997) terdiri dari perilaku membantu orang tertentu (altruism), perilaku yang melebihi syarat minimum, kemampuan toleransi dengan tidak mengeluh (sportsmanship), seorang individu yang bertanggung jawab dalam kehidupan organisasi (civic virtue), keadaan seorang individu dalam menjaga hubungan baik dengan rekan kerja (courtesy).

\section{Kepuasan Kerja}

Mangkunegara (2013) mendefinisikan kepuasan kerja sebagai perasaan menunjang ataupun tidak yang dialami karyawan dalam bekerja ataupun yang berhubungan dengan pekerjaannya. Sutrisno (2014) menyatakan sikap yang dilakukan oleh seorang karyawan terhadap pekerjaanya seperti hal yang berkiatan dengan faktor fisiologis dan psikologis di dalam pekerjaan, imbalan ataupun reward yang diterima dalam pekerjaan, kerja sama antar sesama rekan kerja, dan berhubungan baik antar sesama rekan kerja merupakan kepuasan kerja. Sedangkan menurut Asepta \& Maruno (2017) kepuasan kerja diidentifikasi sebagai suatu prespektif individu yang ada kaitannya dengan pemikiran positif dan negatif terhadap pekerjaan yang dimiliki. Pengukuran yang digunakan dalam penelitian ini ialah indikator Gilmer (1971) terdiri kesempatan untuk dapat maju, keamanan dalam bekerja, pendapatan, manajemen perusahaan, pengawasan yang ada dalam perusahaan, faktor esensial dalam pekerjaan, kondisi iklim kerja, bagian sosial dalam pekerjaan, hubungan baik, dan fasilitas perusahaan yang memuaskan.

\section{Kinerja Karyawan}

Mangkunegara (2013) mendefinisikan kinerja karyawan merupakan sebuah prestasi kerja atau pekerjaan yang telah diselesaikan oleh seorang pekerja baik dalam kualitas maupun jumlah dalam menyelesaikan kewajiban pekerjaannya sesuai dengan tugas yang diberikan kepadanya. Hasibuan (2009) mendefinisikan kinerja (prestasi kerja) sebagai pencapaian yang dihasilkan dari seseorang yang telah menyelesaikan kewajiban yang diberikan berdasarkan kecakapan, pengalaman, kesunghan dan waktu. Pengukuran yang digunakan dalam penelitian ini ialah indikator Mathis \& Jackson (2006) kuantitas dari hasil (quantity of output), kualitas dari hasil (quality of output), ketepatan waktu dari hasil (timeliness of output), kehadiran (presence of work), dan kemampuan bekerjasama (cooperativeness).

\section{Hubungan antar Variabel}

Peran terbesar untuk dapat meningkatkan kinerja karyawan atau performa kerja adalah dengan meningkatkan kecerdasan emosional (Risma, 2012). Lopes et al. (2006) membuktikan bahwa kinerja karyawan secara signifikan positif dapat dipengaruhi oleh kecerdasan emosional. Pembuktian mengenai positif dan signifikansinya kecerdasan emosional dalam memberikan pengaruhnya terhadap kinerja karyawan telah dibuktinya melalui berbagai penelitian terdahulu, di antaranya yaitu penelitian Yusnaena \& Perdana (2015), Pratama \& Suhaeni (2017), Kristianingsih \& Darmastuti (2015) dan Adjma et al. (2014).

H1 : Kecerdasan emosional berpengaruh signifikan positif terhadap kinerja karyawan pada Pabrik Gula Lestari Nganjuk. 
Guruh Grahandika \& Dewie Tri Wijayati. Pengaruh Kecerdasan Emosional, Organizational Citizenship Behavior, dan Kepuasan Kerja terhadap Kinerja Karyawan

Purba \& Seniati (2004) menyatakan bahwa meningkatnya produktifitas kerja merupakan manfaat dari adanya OCB. Didukung penelitian Lestari \& Ghaby (2018) yang membuktikan bahwa adanya suatu hasil secara signifikan positif kinerja karyawan dapat dipengaruhi oleh OCB. Adapun pembuktian mengenai positif dan signifikansinya OCB dalam memberikan pengaruhnya terhadap kinerja karyawan telah dibuktinya melalui berbagai penelitian terdahulu, di antaranya yaitu penelitian Suzana (2017) dan Wijaya (2018).

H2: Organizational citizenship behavior (OCB) berpengaruh signifikan positif terhadap kinerja karyawan pada Pabrik Gula Lestari Nganjuk.

Perlu adanya beberapa faktor pendorong sehingga kepuasan kerja akan muncul dalam individu dan berpengaruh terhadap peningkatan prestasi kerja (Supriyanto \& Troena, 2012). Fadhil \& Mayowan (2018) dan Indrawati (2013) membuktikan di mana kinerja karyawan dapat dipengaruhi oleh kepuasan kerja.

H3 : Kepuasan kerja berpengaruh signifikan positif terhadap kinerja karyawan pada Pabrik Gula Lestari Nganjuk.

H4 : Kecerdasan emosional, OCB dan kepuasan kerja secara bersama-sama berpengaruh signifikan positif terhadap kinerja karyawan pada Pabrik Gula Lestari Nganjuk.

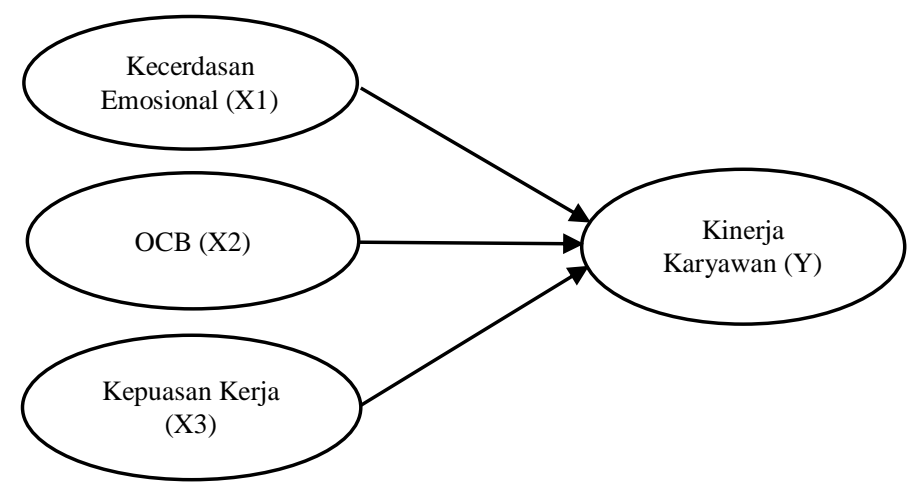

Gambar 1. KERANGKA KONSEPTUAL

\section{METODE PENELITIAN}

Jenis penelitian dalam penelitian ini ialah kuantitatif. Objek penelitian ini pada PT. Perkebunan Nusantara X Pabrik Gula Lestari Nganjuk yang beralamat di Desa Ngrombot, Kecamatan Patianrowo, Kabupaten Nganjuk. Wawancara, kuesioner yang disebarkan secara langsung di lapangan dan observasi digunakan sebagai teknik pengumpulan data dalam penelitian ini. Skala Likert 1-5 digunakan sebagai skala pengukuran pada pengkajian ini. Populasi pada penelitian ini berjumlah 185 karyawan. Rumus slovin dipergunakan dalam penelitian ini sebagai teknik pengambilan sampel dengan tingkat akurasi yaitu 5\% $(\mathrm{a}=0.05)$ dan $95 \%$ tingkat kepercayaan yang diterima. Rumus slovin mengacu pada Husein (2008) disajikan pada persamaan (1).

$n=\frac{N}{1+N e^{2}}$.

$\begin{array}{ll}\mathrm{n} & : \text { Total anggota sampel } \\ \mathrm{N} & : \text { Total populasi } \\ \mathrm{e}^{\mathrm{e}} & \text { : Presisi }\end{array}$

Diperoleh sampel sebesar 128 responden dari hasil perhitungan menggunakan rumus slovin. Data diolah menggunakan software SPSS 23 dengan menggunakan teknik analisis regresi linier berganda. 


\section{HASIL DAN PEMBAHASAN}

\section{Uji Validitas dan Uji Reliabilitas}

Uji validitas pada penelitian ini dilakukan dengan cara membandingkan nilai r-hitung dengan r-tabel untuk (df) $=\mathrm{n}-2$ (Ghozali, 2018). Sehingga, untuk (df) $=128-2=126$ didapatkan R-tabel 0,173. Hasil uji validitas penelitian ini sebagai berikut:

Tabel 1.

UJI VALIDITAS VARIABEL DAN UJI RELIABILITY VARIABEL

\begin{tabular}{|c|c|c|c|c|c|}
\hline Variabel & $\begin{array}{c}\text { Corrected-item } \\
\text { total correlation } \\
\text { tertinggi }\end{array}$ & $\begin{array}{c}\text { Corrected-item } \\
\text { total correlation } \\
\text { terendah }\end{array}$ & $R$-tabel & Cronbach's Alpha & Keterangan \\
\hline $\mathrm{X} 1$ & 0,544 & 0,187 & 0,173 & 0,783 & $\begin{array}{l}\text { Valid dan } \\
\text { Reliabel }\end{array}$ \\
\hline $\mathrm{X} 2$ & 0,692 & 0,178 & 0,173 & 0,741 & $\begin{array}{l}\text { Valid dan } \\
\text { Reliabel }\end{array}$ \\
\hline X3 & 0,566 & 0,216 & 0,173 & 0,813 & $\begin{array}{l}\text { Valid dan } \\
\text { Reliabel }\end{array}$ \\
\hline $\mathrm{Y}$ & 0,512 & 0,190 & 0,173 & 0,672 & $\begin{array}{l}\text { Valid dan } \\
\text { Reliabel }\end{array}$ \\
\hline
\end{tabular}

Sumber : Output SPSS

Berdasarkan tabel 1 dari setiap butir pernyataan yang diberikan kepada responden, memiliki nilai corrected item total lebih besar daripada r-tabel yaitu 0,173 . Dengan demikian semua pernyataan dapat dikatakan valid.

Uji reliabilitas yang digunakan pada penelitian ini menggunakan uji statistik Cronbach's Alpha $(\alpha)$. Suatu variabel dapat dikatakan reliabel jika nilai Cronbach's Alpha> 0,70 (Ghozali, 2018). Namun ada juga yang menyebutkan bahwa nilai Croanbach's Alpha dikatakan reliabel apabila lebih besar dari 0,60 (Siregar, 2014). Berdasarkan tabel 1, nilai Cronbach's Alpha yang dihasilkan dari semua variabel yang telah diuji memiliki nilai di atas 0,60. Jadi seluruh variabel dalam penelitian ini dapat dikatakan reliabel.

\section{Uji Regresi Linier Berganda}

Dalam penelitian ini diperoleh persamaan model regresi berganda berdasarkan output hasil regresi linier berganda pada persamaan (2).

$\mathrm{Y}=1,655+0,018 \mathrm{X} 1+0,200 \mathrm{X} 2+0,194 \mathrm{X} 3+\mathrm{e}$

Tabel 2.

HASIL REGRESI LINIER BERGANDA

\begin{tabular}{lccccc}
\hline \multicolumn{1}{c}{ Model } & Unstandardized B & $\begin{array}{c}\text { Coefficients } \\
\text { Std. Error }\end{array}$ & $\begin{array}{c}\text { Standardized } \\
\text { Coefficients Beta }\end{array}$ & T & Sig \\
\hline (Constant) & 1,655 & .317 & & 5.224 & .000 \\
Kecerdasan & .018 & .077 & .265 & 2.822 & .006 \\
Emosional & .200 & .089 & .224 & 2.234 & .027 \\
OCB & .194 & .094 & .200 & 2.053 & .042 \\
Kepuasan Kerja & & & &
\end{tabular}

Sumber: Output SPSS

Pada tabel 2, diperoleh hasil regresi linier berganda untuk pengujian hipotesis. Diketahui nilai masingmasing uji $t$ variabel dependen dengan variabel independen. Tingkat signifikansi sebesar $0,006(<0,05)$ dan 2,822 ialah nilai dari thitung variabel kecerdasan emosional. Sehingga memiliki arti bahwa H1 diterima, di mana kecerdasan emosional memilliki pengaruh secara signifikan dengan kinerja karyawan. Variabel OCB mempunyai tingkat signifikansi sebesar 0,027 $(<0,05)$ dan nilai thitung 2,234. 
Guruh Grahandika \& Dewie Tri Wijayati. Pengaruh Kecerdasan Emosional, Organizational Citizenship Behavior, dan Kepuasan Kerja terhadap Kinerja Karyawan

Sehingga memiliki arti bahwa $\mathrm{H} 2$ diterima, di mana OCB memiliki pengaruh signifikan dengan kinerja karyawan. Variabel kepuasan kerja memiliki tingkat signifikansi sebesar 0,042 $(<0,05)$ dan t hitung 2,053. Hal tersebut mempunyai arti bahwa $\mathrm{H} 3$ diterima, sehingga kepuasan kerja memiliki pengaruh signifikan dengan kinerja karyawan.

\section{Uji Signifikansi Simultan (Uji F)}

Uji stastistik F menunjukkan apakah setiap variabel independen yang dimasukkan ke dalam model secara bersama-sama memengaruhi variabel dependen. Jika signifikansi lebih kecil dari 0,05 maka semua variabel independen secara bersama-sama memengaruhi variabel dependen (Ghozali, 2018).

Tabel 3.

HASIL UJI F

\begin{tabular}{cccccc}
\hline Model & Sum of Squares & Df & Mean Square & F & Sig \\
\hline Regresion & 3.356 & 3 & 1.119 & 21.765 & $.000^{\mathrm{b}}$ \\
Residual & 6.374 & 124 & .051 & & \\
Total & 9.730 & 127 & & & \\
\hline
\end{tabular}

Sumber: Output SPSS

Nilai signifikansi uji $\mathrm{F}$ pada tabel 3 kurang dari 0,05 yaitu 0,000 . Artinya kecerdasan emosional, organizational citizenship behavior (OCB), dan kepuasan kerja sebagai variabel independen secara simultan (bersama-sama) berpengaruh positif terhadap kinerja karyawan.

Koefisien determinasi $\left(\mathrm{R}^{2}\right)$ digunakan untuk mengukur seberapa jauh kapasitas model dalam menerangkan variasi variabel terikat. Nilai koefisien determinasi antara nol dan satu(Ghozali, 2018). Nilai adjusted $\mathrm{R}^{2}$ pada model regresi sebesar 0,329. Variasi variabel kecerdasan emosional, OCB dan kepuasan kerja dapat menjelaskan sebesar $32,9 \%$ pada variasi kinerja karyawan. Sedangkan sebesar $67,1 \%$ dapat dijelaskan oleh variabel lain di luar penelitian ini.

\section{Pengaruh Kecerdasan Emosional terhadap Kinerja Karyawan pada PT. Perkebunan Nusantara X Pabrik Gula Lestari Nganjuk}

Hasil analisis statistik menunjukkan kecerdasan emosional berpengaruh signifikan positif terhadap kinerja karyawan Pabrik Gula Lestari Nganjuk. Nilai koefisien variabel kecerdasan emosional bernilai positif di mana menunjukkan apabila kecerdasan emosional seorang karyawan semakin tinggi, maka akan semakin tinggi tingkat kinerjanya.

Berdasarkan observasi yang dilakukan pada karyawan PT. Perkebunan Nusantara X Pabrik Gula Lestari Nganjuk, karyawan memiliki motivasi diri yang tinggi, sehingga karyawan terdorong untuk melakukan pekerjaan lebih baik dari sebelumnya. Selain itu karyawan Pabrik Gula Lestari Ngantuk juga memiliki kesadaran dan mengerti akan kelemahan yang dimiliki serta menyadari sepenuhnya akan pekerjaan yang bisa mereka lakukan. Karyawan juga menunjukkan sikap terhadap sesama rekan kerja yaitu sikap saling membantu menenangkan dan memberikan solusi apabila ada yang sedang beradadalam kesulitan kerja. Dalam hal ini kecerdasan emosional ditunjukkan dengan kesadaran diri (self awareness). Karyawan juga sering melakukan diskusi sesama rekan kerja diluar jam kantor dan saling meminta pendapat sebelum menghadap kepada atasan.

Sikap membangun sebuah hubungan yang baik terhadap orang lain merupakan kecerdasan emosional. Hal tersebut ditunjukkan dari sikap antar sesama karyawan yang saling menjaga komunikasi. Hubungan yang baik dengan banyak orang, terumata dalam bidang pekerjaan sangatlah diharapkan dan diperlukan. Sudah menjadi keharusan di dalam lingkungan kerja dan menjadi bagian dalam pekerjaan itu sendiri untuk dapat berhubungan maupun berkomunikasi dengan baik. Karyawan yang mampu untuk mengelola emosi yang dimiliki serta permasalahan yang dihadapi dalam pekerjaannya lebih mudah terselesaikan apabila seorang karyawan cerdas secara emosional. 
Oleh sebab itu, dampak yang sangat baik terhadap kinerja karyawan Pabrik Gula Lestari Nganjuk, baik dalam diri sendiri berupa motivasi diri (sel motivation) maupun kemampuan self awareness terhadap pekerja lain memberikan pengaruh yang positif terhadap kinerja karyawan itu sendiri. Sehingga H1 diterima. Hasil penelitian ini didukung oleh penelitian Wijayati et al. (2020) dan Yusnaena \& Perdana (2015) bahwa kinerja karyawan dapat dipengaruhi oleh kecerdasan emosional secara positif dan signifikan. Dalam penelitian tersebut menguji antara tiga variabel yaitu emotional intelligence, spiritual intelligence (independen variabel) dan employee performance (dependent variabel). Hasil penelitian lainnya oleh Pratama \& Suhaeni (2017) dan Kristianingsih \& Darmastuti (2015) yang menjelaskan bahwa kecerdasan emosional memberikan pengaruh secara positif serta signifikan pada kinerja karyawan. Lopes et al. (2006) dalam studinya terhadap karyawan bagian administrasi dari departemen keuangan sebuah perusahaan asuransi didapati memberikan pengaruh positif serta signifikan terhadap kinerja karyawan. Menurutnya kecerdasan emosional sanggup berkontribusi pada kinerja dengan memungkinkan seorang individu untuk dapat menjaga hubungan baik di tempat kerja, dapat bekerja sama secara efektif didalam timnya serta membangun hubungan sosial antar sesama.

\section{Pengaruh Organizational Citizenship Behavior (OCB) terhadap Kinerja Karyawan pada PT. Perkebunan Nusantara X Pabrik Gula Lestari Nganjuk}

Hasil analisis statistik menunjukkan organizational citizenship (OCB) berpengaruh signifikan positif terhadap kinerja karyawan Pabrik Gula Lestari Nganjuk. Nilai koefisien variabel OCB bernilai positif di mana menunjukkan apabila seorang karyawan memiliki tingkat OCB yang tinggi, maka akan semakin tinggi tingkat kinerjanya.

Berdasarkan observasi yang dilakukan menunjukkan bahwa pada karyawan PT. Perkebunan Nusantara X Pabrik Gula Lestari Nganjuk didapati bilamana terdapat rekan kerja yang tidak masuk maka karyawan lain menggantikannya bahkan mengerjakan tugas rekan kerjanya tersebut. Disisi lain, banyak karyawanyang peduli akan kelangsungan hidup perusahaan dan mematuhi peraturan serta tata tertib yang ada seperti datang lebih awal untuk melakukan do'a bersama sekaligus secara bergiliran setiap hari membaca visi misi perusahaan sebelum memulai aktivitas kerja. Perilaku extra-role karyawan Pabrik Gula Lestari Nganjuk juga terlihat dari karyawan yang saling memberikan masukan yang dapat membangun di tempat kerja. Sehingga $\mathrm{H} 2$ diterima.

Hasil penelitian ini didukung oleh penelitian Lestari \& Ghaby (2018), Suzana (2017), danWijaya (2018) memberikan hasil bahwa OCB memengaruhi secara positif serta signifikan terhadap kinerja karyawan. Hasil peneltian lainnya oleh Sharma \& Mahajan (2017) dalam penelitiannya menyebutkan jika OCB memberi pengaruh positif serta signifikan terhadap kinerja organisasi. Dalam studinya melibatkan karyawan Bank di India. Hal yang sama juga didukung oleh penelitian Vipraprastha et al. (2018) dalam studinya PT. Sarana Arga Gemeh Amerika (SAGA) Denpasar di mana OCB dapat memberikan pengaruh secara positif serta signifikan terhadap kinerja. Menurutnya salah satu manfaat dari adanya organizational citizenship behavior (OCB) adalah dapat mengurangi apabila terjadi perselisihan di tempat kerja serta dapat meningkatkan efisiensi kerja. Perilaku OCB secara tidak langsung dapat menghasilkan hasil yang positif atau hasil yang baik bagi perusahaan, dengan demikian hal tersebut baik untuk perusahaan kedepannya dan juga baik untuk kehidupan sosial yang ada di dalam perusahaan itu sendiri.

\section{Pengaruh Kepuasan Kerja terhadap Kinerja Karyawan pada PT. Perkebunan Nusantara X Pabrik Gula Lestari Nganjuk}

Hasil analisis statistik menunjukkan kepuasan kerja berpengaruh signifikan positif terhadap kinerja karyawan Pabrik Gula Lestari Nganjuk. Nilai koefisien variabel kepuasan kerja bernilai positif di mana menunjukkan apabila seorang karyawan memiliki tingkat kepuasan kerja yang tinggi terhadap pekerjaannya, maka akan semakin tinggi tingkat kinerjanya.

Berdasarkan observasi yang dilakukan menunjukkan bahwa pada karyawan PT. Perkebunan Nusantara X Pabrik Gula Lestari Nganjuk merasa puas terhadap hasil kerjanya. Di mana hal tersebut didukung faktor atasan yang selalu memantau dan mengawasi pekerjaan yang dilakukan para karyawan, sehingga 
apabila karyawan mengalami kesulitan, atasan akan turun langsung untuk memberikan bantuan serta motivasi agar tetap semangat dalam bekerja dan menyelesaikan pekerjaannya. Hal tersebut merupakan salah satu yang menyebabkan kepuasan kerja karyawan semakin meningkat, adanya dukungan baik dari atasan maupun sesama rekan kerja dapat memberikan motivasi bagi pekerja sehingga dapat berpengaruh terhadap pada kinerja karyawan.

Karyawan merasa puas bekerja di lingkungan Pabrik Gula Lestari Nganjuk dalam hal sistem pemberian gaji yang telah berjalan selama ini dan juga intensif yang diberikan apabila perusahaan mencapai target produksi. Hal tersebut memberikan kepuasan bagi karyawan apabila mencapai target yang telah ditetapkan oleh perusahaan, di mana dapat memotivasi karyawan untuk meningkatkan produktivitasnya. Sehingga H3 diterima. Hasil penelitian ini didukung oleh penelitian Fadhil \& Mayowan (2018) di mana kinerja karyawan dipengaruhi secara positif serta signifikan kepuasan kerja dengan kinerja karyawan. Begitu pula penelitian lainnya oleh Indrawati (2013) yang memaparkan hasil bahwa kepuasan kerja memengaruhi employee performance secara positif serta signifikan. Menurutnya seorang karyawan dapat dengan giat serta mengeluarkan potensi yang dimiliki dengan sangat baik apabila karyawan tersebut merasakan kepuasan kerja terhadap pekerjaannya.

\section{Pengaruh Kecerdasan Emosional, Organizational Citizenshio Behavior (OCB), dan Kepuasan Kerja terhadap Kinerja Karyawan pada PT. Perkebunan Nusantara X Pabrik Gula Lestari Nganjuk}

Hasil analisis statistik menunjukkan secara bersamaan kecerdasan emosional, organizational citizenship behavior (OCB) dan kepuasan kerja berpengaruh signifikan positif terhadap kinerja karyawan Pabrik Gula Lestari Nganjuk. Seorang karyawan yang memiliki kecerdasan emosional lebih peduli terhadap kelangsungan hidup perusahaan dan lingkungan kerjanya, yang mana memberikan dampak atau memengaruhi terhadap kepuasan kerja seorang karyawan sehingga seorang karyawan dapat menunjukkan kinerja terbaiknya di dalam organisai atau perusahaan di mana kondisi ini sesuai pada apa yang terjadi di lapangan.

Dalam hal ini kecerdasan emosional ditunjukkan dengan kesadaran diri (self awareness). Karyawan juga sering melakukan diskusi sesama rekan kerja diluar jam kantor dan saling meminta pendapat sebelum menghadap kepada atasan. Dalam hal perilaku OCB, bilamana terdapat rekan kerja yang tidak masuk maka karyawan lain menggantikannya bahkan mengerjakan tugas rekan kerjanya tersebut. Di sisi lain, banyak karyawanyang peduli akan kelangsungan hidup perusahaan dan mematuhi peraturan serta tata tertib yang ada seperti datang lebih awal untuk melakukan do'a bersama sekaligus secara bergiliran setiap hari membaca visi misi perusahaan sebelum memulai aktivitas kerja. Serta, dalam hal kepuasan kerja didukung faktor atasan yang selalu memantau dan mengawasi pekerjaan yang dilakukan para karyawan, sehingga apabila karyawan mengalami kesulitan, atasan akan turun langsung untuk memberikan bantuan serta motivasi agar tetap semangat dalam bekerja dan menyelesaikan pekerjaannya. Sehingga berdasarkan tingkat kesadaran diri, perilaku suka rela dari beberapa karyawan serta pimpinan yang memberikan perhatian kepada para bawahannya hal tersebut secara bersama-sama dapat memengaruhi peningkatan pada kinerja karyawan.

\section{KESIMPULAN}

Secara signifikan positif kecerdasan emosional memberikan pengaruh terhadap kinerja karyawan. Hal tersebut menunjukkan meningkatnya kecerdasan emosional seorang karyawan dapat memengaruhi peningkatan kinerja karyawan. Secara signifikan positif Organizational Citizenship Behavior (OCB) memberikan pengaruh terhadap kinerja karyawan. Hal tersebut menjelaskan bahwa kinerja karyawan akan mengalami peningkatan apabila OCB pada diri karyawan tinggi. Secara signifikan positif kepuasan kerja memberikan pengaruh terhadap kinerja karyawan. Hal tersebut mejelaskan di mana seorang karyawan akan semakin tinggi kinerjanya apabila karyawan tersebut merasa puas.

Berdasarkan hasil penelitian ini, walapun hasil prapenelitian menunjukkan beberapa masalah yang berkaitan dengan kecerdasan emosional, OCB dan tingkat kepuasan kerja karyawan, namun, secara keseluruhan para karyawan telah menunjukkan tingkat kesadaran diri yang dalam hal ini adalah 
implementasi kecerdasan emosional, perilaku suka rela beberapa karyawan yang bersedia membantu karyawan lainnya serta perhatian atasan kepada para bawahan, hal ini diharapkan bisa terus diimplementasikan agar menjadi suatu budaya kerja yang baik. Implikasi bagi perusahaan diharapkan agar menjaga kinerja karyawannya dengan membentuk komunikasi dan budaya kerja yang selama ini telah dilakukan berdasarkan nilai-nilai kecerdasan emosional, tingkat OCB dan kepuasan karyawan. Selain itu juga dapat memberikan motivasi kerja kepada karyawan di perusahaan dengan memberikan reward melalui berbagai program yang mana dapat meningkatkan prestasi kerja dan peningkatan kinerja karyawan.

Keterbatasan dalam penelitian ini ialah sampel yang digunakan hanyalah karyawan tetap pada Pabrik Gula Lestari Nganjuk. Penelitian ke depannya diharapkan untuk dapat memerbanyak jumlah sampel yang ada (tidak hanya karyawan tetap) sehingga hasil yang didapatkan nantinya dapat menyeluruh dan lebih mendalam. Selain itu penelitian selanjutnya untuk memungkinkan dapat mengembangkan studi ini dengan menambahkan variabel lain seperti kecerdasan intelektual, kecerdasan spiritual maupun kecerdasan budaya.

\section{DAFTAR PUSTAKA}

Adiyasa, N. I. W., \& Windayanti. (2019). Pengaruh Motivasi, Kepuasan Kerja, dan Kepemimpinan terhadap Kinerja Karyawan PT . XYZ. Jurnal Manajemen Strategi dan Aplikasi Bisnis, 2(1), 23 30 .

Adjma, Djumarno, \& Nasikin. (2014). Emosional dan Kecerdasan Spiritual terhadap Kinerja Karyawan pada PT . Telkom Jakarta Selatan. Jurnal Manajemen Mutu, 13(1), 33-39.

Ardiana, I. D. K. R. (2008). Mendorong dan Mengarahkan Perilaku SDM dalam Kehidupan Organisasi Bisnis di Era Global. Jurnal Ilmu Ekonomi dan Manajemen, 5(1), 121-138.

Asepta, U. Y., \& Maruno, S. H. P. (2017). Analisis Pengaruh Work-Life Balance dan Pengembangan Karir terhadap Kepuasan Kerja Karyawan PT.Telkomsel, Tbk Branch Malang. Jurnal Ilmiah Bisnis dan Ekonomi Asia, 11(1), 77-85.

Fadhil, A., \& Mayowan, Y. (2018). Pengaruh Motivasi Kerja dan Kepuasan Kerja terhadap Kinerja Karyawan AJB Bumiputera. Jurnal Administrasi Bisnis, 54(1), 40-47.

Ghozali, I. (2018). Aplikasi Analisis Multivariete dengan Program IBM SPSS 25 (Kesembilan). Semarang: Universitas Diponogoro.

Gibson, J. L., Ivancevich, J. M., Donnelly, J. H., \& Konopaske, R. (1997). Organisasi: Perilaku, Struktur, Proses. Jilid 2. Alih Bahasa. Jakarta: Binarupa Aksara

Gilmer, B. V. H. (1971). Industrial and organizational psychology. New York: Mc Graw-Hill Book Company.

Goleman, D. 2004. Emotional Intelligence (Kecerdasan Emosional) Mengapa EI lebih penting daripada IQ, terj T. Hermaya, Jakarta: PT Gramedia Pustaka Utama.

Hasibuan, M. (2009). Manajemen Sumber Daya Manusia. Jakarta: Bumi Aksara.

Husein, U. (2008). Metode Penelitian Untuk Skripsi dan Tesis Bisnis. Jakarta: Rajagrafindo Persada.

Indrawati, A. D. (2013). Pengaruh Kepuasan Kerja terhadap Kinerja Karyawan dan Kepuasan Pelanggan pada Rumah Sakit Swasta di Kota Denpasar. Jurnal Manajemen, Strategi Bisnis dan Kewirausahaan, 7(2), 135-142. 
Guruh Grahandika \& Dewie Tri Wijayati. Pengaruh Kecerdasan Emosional, Organizational Citizenship Behavior, dan Kepuasan Kerja terhadap Kinerja Karyawan

Khan, R. A., Bukhari, S. Z., Humayon, A. A., \& Khan, M. M. (2019). Influence of Individual Emotional Intelligence Dimension on Employee Performance Working in Banks. City University Research Journal, 9(3), 606-627.

Kristianingsih, T. P., \& Darmastuti, I. (2015). Pengaruh Kecerdasan Emosi terhadap Kinerja Pegawai dengan Ambiguitas Peran sebagai Variabel Intervening. Diponegoro Journal of Management, $4(2), 1-10$.

Lestari, E. R., \& Ghaby, N. K. F. (2018). Pengaruh Organizational Citizenship Behavior (OCB) terhadap Kepuasan Kerja dan Kinerja Karyawan. Jurnal Teknologi dan Manajemen Agroindustri, 7(12), 116-123.

Lopes, P. N., Grewal, D., Kadis, J., Gall, M., \& Salovey, P. (2006). Evidence that Emotional Intelligence is Related to Job Performance and Affect and Attitudes at Work. Psicothema, 18, $132-138$.

Mangkunegara, A. P. (2013). Manajemen Sumber Daya Manusia Perusahaan. Bandung: PT Remaja Rosdakarya.

Mathis, R. L., \& Jackson, J. H. (2006). Human Resource Management (Kesepuluh). Jakarta: Salemba Empat.

Mulyasari, I. (2018). Pengaruh Kecerdasan Emosional dan Kompetensi terhadap Kinerja Pegawai. Journal of Management Review, 2(2), 190-197.

Pratama, A. Y., \& Suhaeni, T. (2017). Pengaruh Kecerdasan Emosional terhadap Kinerja Karyawan. Jurnal Riset Bisnis dan Investasi, 3(2), 51-62.

Purba, D. E., \& Seniati, A. N. L. (2004). Pengaruh Kepribadian dan Komitmen Organisasi terhadap Organizational Citizenship Behavior. Makara, Sosial Humaniora, 8(3), 105-111.

Risma, D. (2012). Pengaruh Kecerdasan Emosional terhadap Kinerja Karyawan. Educhild, 1(1), 8697.

Sharma, K., \& Mahajan, P. (2017). Relationship between Emotional Intelligence and Organisational Citizenship Behaviour among Bank Employees. Pacific Business Review International, 9(11), $20-29$.

Supriyanto, A. S., \& Troena, E. A. (2012). Pengaruh Kecerdasan Emosional dan Kecerdasan Spiritual terhadap Kepemimpinan Transformasional, Kepuasan Kerja dan Kinerja Manajer (Studi di Bank Syari'ah Kota Malang)‘. Jurnal Aplikasi Manajemen, 10(4), 693-709.

Vipraprastha, T., Sudja, I. N., \& Yuesti, A. (2018). The Effect of Transformational Leadership and Organizational Commitment to Employee Performance with Citizenship Organization (OCB) Behavior as Intervening Variables (At PT Sarana Arga Gemeh Amerta in Denpasar City). International Journal of Contemporary Research and Review, 9(02), 20503-20518.

Wijaya, O. Y. A. (2018). The Role of Organizational Citizenship Behavior as Mediation Variables Between Organizational Commitments and Employee Performance: Evidence From the Hospitality Industry in Surabaya. Jurnal Aplikasi Manajemen, 18(1), 130-141.

Wijayati, D. T., Kautsar, A., \& Karwanto, K. (2020). Emotional Intelligence, Work Family Conflict, and Job Satisfaction on Junior High School Teacher's Performance. International Journal of Higher Education, 9(1), 179-188. 
Yani, A. S., \& Istiqomah, A. (2016). Pengaruh Kecerdasan Intelektual dan Kecerdasan Emosional terhadap Kinerja Karyawan dengan Profesionalisme sebagai Variabel Intervening (Studi Empiris Terhadap PT. JNE Service Center Utara 1). Media Studi Ekonomi, 19(2), 1-14.

Yusnaena, \& Perdana, A. (2015). Emotional Intelligence Effect and Side of Gender Spritual Intelligence against Performance of Employees in the West Sumatra Staffing Parliament. DeReMa (Development Research of Management) Jurnal Manajemen, Vol. 10, pp. 138-158. 